\title{
Correlation between Campanacci's radiological classification of giant cell tumor of bone and expression of Cyclin D1 and PCNA
}

\author{
Eréndira G. Estrada-Villaseñor, Hidalgo Bravo Alberto, C. Bandala, P. De la Garza-Montano, Reyes Medina Naxieli,
} Pichardo Bahena Raúl, EA. Delgado-Cedillo, LM. Linares-Gonzalez, G. Rico-Martínez

Instituto Nacional de Rehabilitación, Mexico

Received: September 29, 2016

Accepted: January 5, 2017

Online Published: January 10, 2017

DOI: $10.5430 /$ jst.v7n1p47

URL: http://dx.doi.org/10.5430/jst.v7n1p47

\begin{abstract}
Giant cell tumor of bone is considered by his behavior a benign but aggressive neoplasm. The objective of our study was to determine if there is a correlation between the Campanacci's radiological classification of giant cell tumors of bone and the expression by immunohistochemistry of Cyclin D1 and proliferation cell nuclear antibody (PCNA). A retrospective and descriptive study was made. In total, there were 27 cases. All cases showed Cyclin D1 and PCNA positivity. Rho Spearman for Campanacci and Cyclin D1 expression was 0.06 and for Campanacci and PCNA was 0.418. We conclude that there is a positive correlation between PCNA expression in giant cell tumors of Bone and the Campanacci's radiological classification II and III, but Cyclin D1 expression was no related with radiologic features.
\end{abstract}

Key Words: Giant cell tumor bone, Cyclin D1, PCNA, Campanacci's classification

\section{INTRODUCTION}

Giant cell tumor of bone is considered by his behavior a benign but aggressive neoplasm. ${ }^{[1]}$ The clinical, radiological and histological features of this tumor present a broad spectrum: ranging from slow growth to fast growing aggressive lesions with extensive bone destruction and involvement of adjacent soft tissues. ${ }^{[2]}$ Histologically they can have very abundant giant cell tumors alternating with the stromal cells, to moderate or scarce giant cell tumors. There is a Jaffe's histological classification of these tumors ${ }^{[3]}$ and a radiological classification $^{[4]}$ (Campanacci's classification).

In most cases, $\mathrm{X}$-rays are the first diagnostic approach, and until now Enneking's and Campanacci's radiographic clas- sifications are helpful in planning the surgical treatment, ${ }^{[5]}$ but no the histological classification, unless the tumor is malignant. ${ }^{[6]}$

Proliferation cell nuclear antibody (PCNA) and Cyclin D1 are proliferation markers that are overexpressed in neoplasms, ${ }^{[7-9]}$ and their expression is related to the prognosis.

\section{OBJECTIVE}

The objective of study was to determine if there is a correlation between the Campanacci's radiological classification of giant cell tumors of Bone and the expression by immunohistochemistry of Cyclin D1 and PCNA.

\footnotetext{
*Correspondence: Eréndira G. Estrada-Villaseñor; Email: eren_strada71@ @otmail.com; Address: Instituto Nacional de Rehabilitación. Torre de Investigación Planta Baja. Servicio de Anatomía Patológica Calzada México Xochimilco 189 Col Arenal de Guadalupe. Del Tlalpan cp. 13869 Cd de México.
} 


\section{Material AND Methods}

A retrospective and descriptive study was made. Cases of the anatomic pathology archives from 2013, identified by our previous work ${ }^{[10]}$ were selected and also the cases diagnosed in January and February 2015. Initially, we identified 37 cases. When choosing cases that had both the initial radiograph and histological material obtained at a date close to that of the radiological study we had only 27 cases.

\subsection{Immunohistochemistry technique and evaluation}

Immunohistochemical analysis was performed on tissue sections of 3 microns, mounted on slides treated with Poly-Llysine. Endogenous peroxidase was blocked with a solution of $\mathrm{H}_{2} \mathrm{O}_{2}$. The cuts were exposed to primary antibody (cyclin D1 antibody Santa Cruz Biotech and anti-PCNA Abcam) for 30-60 minutes at a dilution of 1: 100 to subsequently be washed with TBST solution. Then were incubated with the secondary antibody, followed by two washes with TBST solution. Peroxidase was applied immediately, with subsequent washing to use diaminobenzidine as chromogen finally. Once washing was performed with TBST, the tissue was counterstained with Harris hematoxylin, dehydrated and mounted for analysis with a light microscope.

A semiquantitative classification was used to evaluate de positivity for Cyclin D1 and PCNA by two independent pathologists (see Table 1). In this classification, the intensity of the expression and the extension were considered. When the sum of both was between 0 and 1 the score was (-), if the sum was 2 and 3 the score was (+), for 4 and 5 the score was $(++)$ and for 6 the score was $(+++)$.

Table 1. Immunohistochemistry score

\begin{tabular}{llll}
\hline Percentage (\%) & Score & Intensity & Score \\
\hline 0 & 0 & Negative & 0 \\
$1-25$ & 1 & Weak & 1 \\
$26-50$ & 2 & Mild & 2 \\
$51-75$ & 3 & Strong & 3 \\
\hline
\end{tabular}

\subsection{Radiological classification of the cases and evalua- tion}

Tumors confined to the bone without cortical expansion were considered Campanacci I. Expansive tumors without cortical disruption were seen as Campanacci IIA, Expansive tumors with focal cortical disruption were considered Campanacci IIB, Tumors with soft tissue extension and without residual cortical were considered Campanacci III.

Two independent radiologists did the Campanacci's classification of the cases.

\subsection{Statistical analysis}

Statistical analysis was performed with SPSS (versión 16.0 for Windows). The number and frequency of each Campanacci's classification, Cyclin D1 and PCNA positivity were calculated. The correlation between Campanacci's classification with Cyclin D1 and PCNA were calculated with no parametric Spearman test. $p<.05$ was considered statistically significant.

Table 2. Giant cell tumor localization

\begin{tabular}{lll}
\hline Localization & Frequency & Percentage (\%) \\
\hline Distal femur & 7 & 25.9 \\
Proximal tibia & 5 & 18.5 \\
Distal radius & 7 & 25.9 \\
Proximal humerus & 1 & 3.7 \\
Sacrum & 2 & 7.4 \\
Proximal fibula & 2 & 7.4 \\
Proximal Ulna & 1 & 3.7 \\
Distal tibia & 1 & 3.7 \\
Pelvis & 1 & 3.7 \\
Total & 27 & 100.0 \\
\hline
\end{tabular}

\section{RESUlts}

In total, there were 27 cases, 19 women and eight men, with a median age of 28 years. The smallest tumor measured 4.5 $\mathrm{cm}$ and the biggest $17 \mathrm{~cm}$. The most frequent tumor locations were distal femur and distal radius (see Table 2). There were not Campanacci I tumors and only Campanacci II and III (see Table 3).

Table 3. Campanacci's radiological classification

\begin{tabular}{lll}
\hline & Frequency & Percentage (\%) \\
\hline Campanacci II & 9 & 33.3 \\
Campanacci III & 18 & 66.7 \\
Total & 27 & 100 \\
\hline
\end{tabular}

Table 4. Expression of Cyclin D1

\begin{tabular}{lll}
\hline Expression Cyclin D1 & Frequency & Percentage (\%) \\
\hline+ & 4 & 14.8 \\
++ & 13 & 48.1 \\
+++ & 10 & 37.0 \\
Total & 27 & 100 \\
\hline
\end{tabular}

All cases showed Cyclin D1 and PCNA positivity; the results are summarized in Table 4 and Table 5.

Table 5. Expression of PCNA

\begin{tabular}{lll}
\hline Expression PCNA & Frequency & Percentage (\%) \\
\hline++ & 15 & 55.6 \\
+++ & 12 & 44.4 \\
Total & 27 & 100 \\
\hline
\end{tabular}


Rho Spearman for Campanacci and Cyclin D1 expression was 0.06 and for Campanacci and PCNA was 0.418 .
D1 immunohistochemistry. Figure 2 shows a Campanacci III case with PCNA and Cyclin immunohistochemistry.

Figure 1 shows a Campanacci II case with PCNA and Cyclin

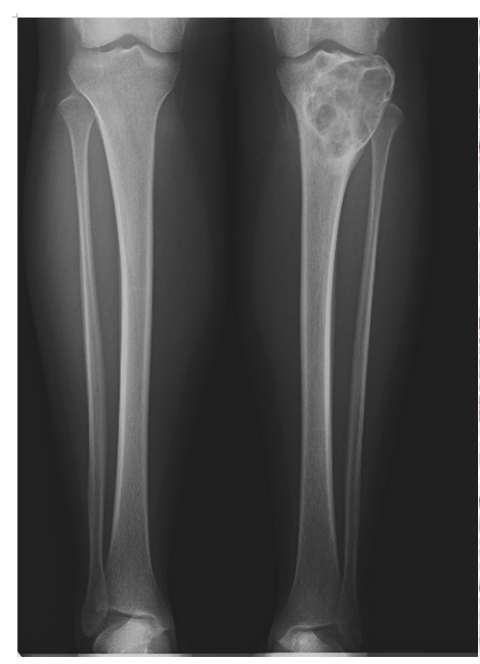

A

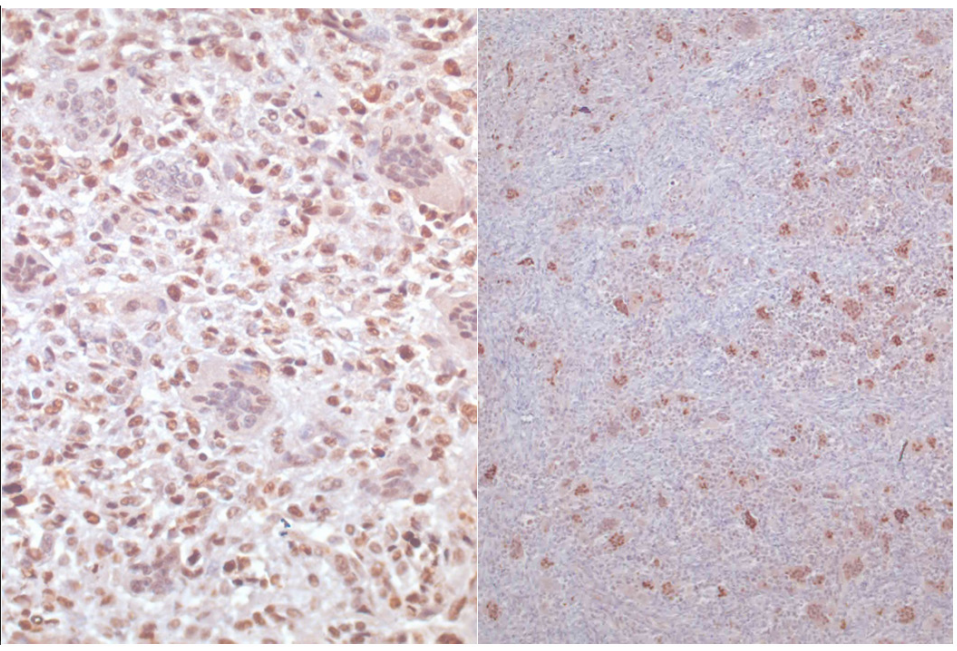

B

C

Figure 1. A) Giant Cell Tumor in proximal tibia Campanacci II. B) PCNA positivity in the nuclei of the stromal cells. There are some stromal cells that are negative, and there are others that stain weakly for PCNA. All the nuclei of the stromal cells are strongly positive. C) Cyclin D1 positivity in the nuclei of the multinucleated giant cells. There are multinucleated giant cells weakly positive and others that are strongly positive.

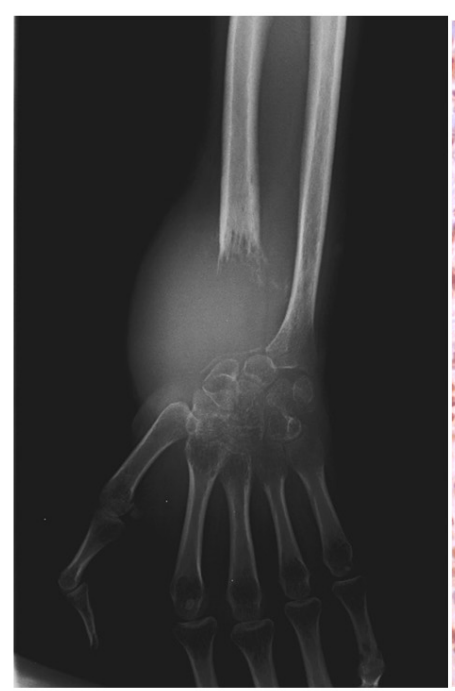

A

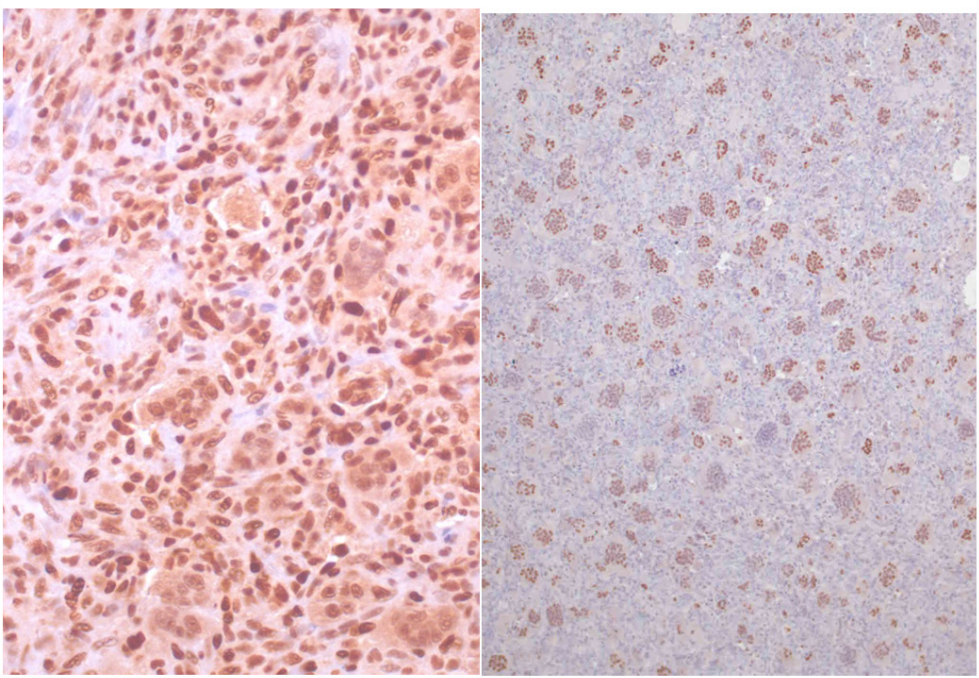

B
$\mathrm{C}$

Figure 2. A) Giant Cell Tumor in distal radius Campanacci III. B) PCNA positivity in the nuclei of the stromal cells. All the stromal cells are strongly positive for PCNA. C) Cyclin D1 positivity in the nuclei of the multinucleated giant cells. There are multinucleated giant cells negative and multinucleated giant cells strongly positive.

\section{Discussion}

Some papers describe the different radiological features of the giant cell tumors of Bone, ${ }^{[1-15]}$ however, doesn't explain why these differences. With our results, we attribute these radiological differences to the various proliferative activity. Therefore, those giant cell tumors radiologically with well- 
defined borders (Campanacci II) have a lower PCNA than those without defined borders and extension to soft tissues (Campanacci III).

Our work is the first that makes a radiological immunohistochemical proliferative correlation in a series of cases of giant cell tumors of bone.

In this study, we investigated whether there was a correlation between expression of Cyclin D1 and PCNA by immunohistochemistry and Campanacci's radiological classification in giant cell tumors of Bone. Our results show that there is a positive correlation between PCNA expression in giant cell tumors of Bone and the Campanacci's radiological classification, but Cyclin D1 expression was no related with radiologic features.

Even our study has the limitation that no cases Campanacci I were present, contributes to the study of giant cell tumors of bone, establishing that there is a relationship between radiology and the expression of PCNA as an indicator of proliferative activity. Our observations are supported by the statistical significance of Spearman's non-parametric test used in these cases $(p<.05)$.

Our results are related to previous observations of Robinson $\mathrm{D}$ et al. who demonstrated in tissue cultures that the stromal cells of giant cell tumors of Bone have a proliferative activity and this proliferative activity correlates with the radiographic stage. ${ }^{[16]}$ In that study growth curves and population doubling times were used as indicators of the proliferative activity. We revisited the issue but instead of culturing stromal cells, we determined by immunohistochemistry the expression of proliferation markers such as PCNA and Cyclin D1 in paraffin blocks.

Cyclin expression in giant cell tumors of Bone has been studied ${ }^{[17-19]}$ by immunohistochemistry. In these studies the particular cellular expression, the differences in primary and recurrent tumors, and the differences between lung lesions and primary tumors was determined.

The only one previous work studied the expression of PCNA by immunohistochemistry in Giant cell tumors of bone. ${ }^{[20]}$ In that study, PCNA was associated with CD147 expression.

We consider that although Jaffe's histological classification is useful to detail the different histological features in the GCT, Giant cell tumors of bone need not a histological classification but a molecular classification that includes the expression of certain proteins that correlate with the clinical and radiological features of the patients.

The future work will be the identification of these proteins.

\section{Conclusions}

We conclude that there is a positive correlation between PCNA expression in giant cell tumors of Bone and the Campanacci's radiological classification II and III, but Cyclin D1 expression was no related with radiologic features.

\section{CONFlicts OF INTEREST Disclosure}

The authors declare that there is no conflict of interest statement.

\section{REFERENCES}

[1] Yasko AW. Giant cell tumor of bone. Curr Oncol Rep. 2002 Nov; 4(6): 520-6. https://doi.org/10.1007/s11912-002-0067-2

[2] Wang H, Wan NJ, Hu YC. Giant cell tumour of bone: a new evaluating system is necessary. International Orthopaedics (SICOT). 2012; 36: 2521-7. PMid:23052276. https://doi .org/10.1007/s002 64-012-1664-9

[3] Jaffe HL, Lichtenstein L, Portis RB. Giant cell tumor of bone: its pathological appearance, grading, supposed variants and treatment. Arch Pathol. 1940; 30: 993-1031.

[4] Campanacci M, Baldini N, Boriani S, et al. Giant cell tumor of bone. J Bone Joint Surg Am. 1987; 69(1): 106-14. PMid:3805057. https://doi.org/10.2106/00004623-198769010-00018

[5] Eckardt JJ, Grogan TJ. Giant cell tumor of bone. Clin Orthop Relat Res. 1986 Mar; (204): 45-58. https ://doi .org/10.1097/0000 3086-198603000-00006

[6] Anract Ph, De Pinieux G, Cottias P, et al. Tomeno1 Malignant giantcell tumours of bone. Clinico-pathological types and prognosis: a review of 29 cases. International Orthopaedics (SICOT). 1998; 22: 19-26. https://doi.org/10.1007/s002640050201

[7] Lv Q, Zhang J, Yi Y, et al. Proliferating Cell Nuclear Antigen Has an Association with Prognosis and Risks Factors of Cancer Patients: a Systematic Review. Mol Neurobiol. 2016 Nov; 53(9): 6209-17.
PMid:26558632 https://doi.org/10.1007/s12035-015-952 5-3

[8] Donnellan R, Chetty R. Cyclin D1 and human neoplasia. Mol Pathol. 1998 Feb; 51(1): 1-7. PMid:9624412. https://doi .org/10.113 $6 / \mathrm{mp} .51 .1 .1$

[9] Jour G, West K, Ghali V, et al. Differential Expression of p16(INK4A) and Cyclin D1 in Benign and Malignant Salivary Gland Tumors: A Study of 44 Cases. Head and Neck Pathol. 2013; Sep; 7(3): 224-31.

[10] Estrada-Villaseñor EG, Linares-González LM, Delgado-Cedillo EA, et al. Prevalencia y características clínico-patológicas del tumor de células gigantes. Acta Ortopédica Mexicana. 2015 Nov-Dec; 29(6): 295-8.

[11] Llanos C, García B, Oyanedel Q, et al. Estudio Radiológico Simple en el Diagnóstico del Tumor de Células Gigantes en Población Pediátrica. Correlación Anatomoradiológica. Revista Chilena de Radiología. 2008; 2: 62-7.

[12] Dorfman HD, Czerniak B. Bone Tumors St. Louis (United States of America) Mosby; Chapter 10, Giant Cell Lesions; 1998. p. 559-89.

[13] Greenspan A, Remagen W. Tumores de huesos y articulaciones. Marbán. 2002: 428.

[14] Mirra JM, Picci P, Gold RH. Bone tumors: clinical, radiologic and pathologic correlations. Lea \& Febiger. 1989: 966. 
[15] Helms CA. Radiología del esqueleto 2a ed. Filadelfia (United States of America); Marbán Libros; Cap 2, lesiones líticas benignas; 1999.

[16] Robinson D, Lewis MM, Nevo Z, et al. The radiographic stage of giant cell tumor related to stromal cells proliferation. Tissue Cultures in 13 cases. Acta Orthop Scand. 1997 Jun; 68(3): 294-7. PMid:9246997. https://doi.org/10.3109/17453679708996705

[17] Kauzman A, Li SQ, Bradley G, et al. Cyclin alterations in giant cell tumor of bone. Mod Pathol. 2003 Mar; 16(3): 210-8. PMid:12640100. https://doi.org/10.1097/01.MP.0000057235.65327.40

[18] Matsubayashi S, Nakashima M, Kumagai K, et al. Immunohistochemical analyses of beta-catenin and cyclin D1 expression in gi- ant cell tumor of bone (GCTB): A possible role of Wnt pathway in GCTB tumorigenesis. Pathol Res Pract. 2009; 205(9): 626-33. PMid:19324500. https://doi.org/10.1016/j.prp.2009.02. 011

[19] Alberghini M, Kliskey K, Krenacs T, et al. Morphological and immunophenotypic features of primary and metastatic giant cell tumour of bone. Virchows Arch. 2010 Jan; 456(1): 97-103. PMid:20012988. https://doi.org/10.1007/s00428-009-0863-2

[20] Han YH, Bo G, Huang JH, et al. Expression of CD147, PCNA, VEGF, MMP's and their clinical significance in the giant cell tumor of bones. Int J Clin Exp Pathol. 2015; 8(7): 8446-52. PMid:26339416. 